Błażej Przybylski*

Warszawa

\title{
Biografie edukacyjne ekstremistów politycznych. Podobieństwa i różnice
}

Kilkadziesiąt lat temu Daniel Bell ogłosił koniec ideologii ${ }^{1}$. Miniony wiek to okres metanarracji, zdolnych zmobilizować miliony ludzi, ślepo i posłusznie podążających w kierunku nakreślonym przez teoretyków i polityków; epoka ideologii, które tłumaczyły i wyjaśniały problemy społeczne i sprzeczności systemowe; czas charyzmatycznych przywódców, za którymi maszerowały setki tysięcy ludzi oddanych im wiernie i bezrefleksyjnie; czas liderów przedstawiających wielkie wizje i atrakcyjne perspektywy oraz utopii budzących nadzieję na nadejście lepszego świata. To także wiek pełen napięć i konfliktów, najpierw pomiędzy komunizmem a faszyzmem, a po upadku tego drugiego między komunizmem a światem zachodnim, opartym na wartościach demokratycznych i kapitalistycznym modelu gospodarki. Zwycięstwo reżimów liberalno-demokratycznych zainspirowało Francisa Fukuyamę do ukucia niezwykle dziś popularnego stwierdzenia o „końcu historii"'. Zdaniem amerykańskiego socjologa, zachodnie systemy demokratyczne tworzą ostatnie stadium rozwoju politycznego. Demokracje liberalne mają być tym właściwym i oczekiwanym punktem historii, w stronę którego

* Dr Błażej Przybylski jest adiunktem w Katedrze Socjologii Edukacji w Wydziale Nauk Pedagogicznych Akademii Pedagogiki Specjalnej w Warszawie.

${ }^{1}$ D. Bell, The end of ideology: on the exhaustion of political ideas in the fifties, Cambridge 2000 .

${ }^{2}$ F. Fukuyama, Koniec historii, Kraków 2009. 
zmierzać będą wszystkie państwa. Mają też stanowić receptę na wszelkie bolączki i dramaty współczesnego świata.

Nieusuwalna cecha demokracji liberalnej - jedna z wielu - to pluralizm opinii i poglądów. Obywatele, których podstawowym zadaniem i obowiązkiem w życiu politycznym wspólnoty jest udział w wyborach, mogą cyklicznie popierać lub odrzucać konkurencyjne siły polityczne. Teoretycznie na rynku dostępne są partie i ugrupowania reprezentujące różne ideologie i nurty. W rzeczywistości - o czym pisze wielu politologów, socjologów i publicystów - wybór ogranicza się do kilku organizacji, stosunkowo potężnych i stabilnych, wspieranych przez prywatny biznes lub dotowanych z kas państwowych. Nie jest to wyłącznie polską specyfiką, także specyfiką zdecydowanej większości państw bogatego zachodu. Zarzuty dotyczące klasy politycznej, skoncentrowanej na medialnych rozgrywkach, pozbawionej nowych wizji i idei, prowadzącej jałowe spory, kierowane są pod adresem dzisiejszej sceny politycznej przez liczne środowiska niezadowolonych. Słabnie wiara w mityczny już niemalże „demokratyczny konsensus”. Coraz częściej pojawiają się głosy oskarżające liberalną odmianę demokracji o sprzeniewierzanie się idei pluralizmu, oznaczającej wielość i różnorodność stylów życia, opinii, stanowisk, ideologii. Liberalna odmiana demokracji sztucznie i uznaniowo zawęża stanowiska dopuszczone do udziału w przestrzeni publicznej, albowiem wyklucza z debaty zarówno opinie nienależące do ,zdroworozsądkowych", jak i grupy pozostające na peryferiach polityki.

Dominujące narracje medialne utwierdzają w przekonaniu o braku wyboru. Proponowane alternatywy uchodzą za niemożliwe do wprowadzenia i w ogóle nie przenikają do głównego nurtu wymiany myśli. „We współczesnym globalnym kapitalizmie niespotykany dotąd poziom osiąnęła ideologiczna naturalizacja - rzadko kto ośmiela się nawet śnić utopijne sny o możliwej alternatywie [...]. Utopie alternatywnych światów są egzorcyzmowane przez utopię panująca, która występuje w masce pragmatycznego realizmu" "3. Wszystkie alternatywne projekty sprzeciwiające się uprawomocnionym treściom są traktowane jako kolejny wybryk grupki szalonych demiurgów. Równie niechętni jakimkolwiek nowym czy też ożywieniu starych zapomnianych ideologii są politycy, żądni utrzymania i powiększenia swoich pozycji i wpływów. Zainteresowani stanowiskami i sukcesem w kolejnych wyborach, mamią obywateli pustymi obietnicami i nic nieznaczącymi frazesami. Uczestnicząc w wyścigu medialnym o rząd dusz, już dawno wywiesili

3 S. Žižek, Od tragedii do farsy, czyli jak historia sie powtarza, Warszawa 2011, s. 132. 
„białe flagi”, symbolizujące rezygnację z mocy sprawczej i zadowolenie się iluzją władzy, która dziś już nie spoczywa w rękach parlamentów i polityków, ale pozostaje ukryta gdzieś indziej. Również w interesie prywatnego kapitału leży trwanie i umacnianie „turbokapitalizmu”, wymykającego się demokratycznej kontroli rządów i państw. Scenę polityczną szczelnie zagospodarowują partie centrum lub zmierzające coraz bardziej w jego stronę. Tradycyjne podziały na lewicę i prawicę tracą na znaczeniu. Różnice pomiędzy partiami, powszechnie nazywanymi lewicowymi i prawicowymi, są coraz mniej widoczne i istotne. Na ogół nie mają one bowiem wiele wspólnego z lewicowością czy prawicowością, potrzebują jedynie dobrze brzmiących i ciagle chwytliwych etykiet dla swoich pustych haseł i programów wyborczych. Częstokroć to jedynie wzajemne uprzedzenia partyjnych liderów lub wzajemne sympatie decydują o przynależności do konkretnej partii.

Gdzieś na uboczu, poza głównym nurtem, funkcjonują jednak organizacje niszowe i stosunkowo nieliczne, których poglądy i stanowiska nie mieszczą się w ramach „konsensusu liberalno-demokratycznego”. Przedmiotem artykułu nie jest charakterystyka ani prezentacja poglądów skrajnych, peryferyjnych i pomijanych. Zdając sobie sprawę z wielowątkowości poszczególnych stanowisk, wielokroć poważnie różniących się od siebie, poruszałem się na tradycyjnej osi lewica i prawica. Konstruując dziś ten trochę już anachroniczny podział, do ideologii należących do nurtu prawicowego zaliczyć można poglądy narodowe, chadeckie, konserwatywno-liberalne, a także centroprawicowe; w szerszym znaczeniu także i te skrajne, jak chociażby faszystowskie czy rasistowskie. $Z$ kolei do lewicy zalicza się, poza nurtami akceptowalnymi w demokratycznej polityce, jak: socjaldemokracja, feminizm czy partie o charakterze ekologicznym, tak zwanych zielonych, również komunizm i anarchizm. Nie będę rekonstruował postulatów każdego $\mathrm{z}$ wymienionych ruchów. $\mathrm{W}$ poniższym artykule zamierzam prześledzić biografie edukacyjne młodych politycznych radykałów. Hegemoniczna pozycja partii centrowych, wspierających demokratyczno-liberalny porządek, wyznacza centrum i szczelnie, z dużą skutecznością odgradza obywateli od innych poglądów, na ogół nieaprobowanych i niedopuszczalnych. Wystarczy wspomnieć, że jeszcze trzydzieści lat temu badani komuniści należeliby do „normalnych” i „typowych” przypadków zaangażowania politycznego, do statystycznej większości. Z kolei w przedwojennej Polsce także i radykalnie prawicowe postawy mieściły się w społecznej „,normie”. W innych sytuacjach

${ }^{4}$ E. Luttwak, Turbokapitalizm: zwycięzcy i przegrani światowej gospodarki, Wrocław 2000. 
historycznych i politycznych nikomu nie przyszłoby do głowy umieszczać bohaterów moich wywiadów wśród ekstremistów. Prędzej znaleźliby się tam centryści, liberałowie czy socjaldemokraci. Konstrukcja ideologicznej mapy ustanawiającej „,centrum” i „peryferyjność” jest wypadkową wielu czynników, w tym głównie systemowych i instytucjonalnych. To dzisiejsza sytuacja polityczna oraz dominujące narracje nakazują (przy)stosowanie się do takich wymogów. W poniższym artykule świadomie poddaję się społecznym konstruktom, które „normalność” i ,zdroworozsądkowość” każą upatrywać w ideologii demokratyczno-liberalnej. Zgodnie z uprawomocnionymi wizjami, młodych o poglądach skrajnie odmiennych od centrum zaliczam do politycznych ekstremistów.

Kryterium klasyfikacji badanych stanowiła ich samoidentyfikacja. Do analizy porównawczej, spośród 19 młodych zaangażowanych politycznie, z którymi przeprowadzałem wywiady narracyjne, wybrałem sześć narracji. Wszyscy badani mieścili się w przedziale wiekowym 18-26 lat. Na podstawie autoidentyfikacji określiłem poglądy sześciu badanych jako skrajne, włączając do poniższej analizy trzech badanych o poglądach skrajnie lewicowych oraz trzech o poglądach skrajnie prawicowych. Kryterium przynależności ideologicznej jest tym, które zastosowałem przy nadawaniu etykiety „ekstremizmu”. Nie zawsze taki ekstremizm musi wiązać się z niskim poparciem społecznym czy też brakiem popularności.

Wśród lewicowych radykałów znalazł się jeden anarchista Olek oraz dwóch komunistów Bartek i Michał. Ta trójka badanych należy do organizacji młodzieżowych o charakterze antysystemowym. Anarchista i komuniści reprezentują różne poglądy, mimo iż wszyscy plasują się na lewicy. Do skrajnej prawicy zaliczyłem Kamila, Mariusza i Romana, członków radykalnie prawicowych ruchów społecznych. Ich opinie o konkretnych wydarzeniach czy stosunek do istniejących partii także nie są identyczne, jednak rdzeń, poglądy i orientacja ideologiczna pozostają przybliżone. Obie „trójki” traktuję łącznie jako pewną całość. Mimo różnic występujących pomiędzy samymi lewicowcami, jak i w obrębie prawicowych radykałów, można pokusić się, z racji pewnych podobieństw tych przypadków, o uogólnienia oraz co w tym artykule stanowi kluczowe zadanie - rekonstrukcję ról i znaczeń agend socjalizacyjnych w procesie stawania się ekstremistą.

Cechą wspólną radykałów jest przynależność do organizacji bądź ruchów rzadko występujących w mediach i nieliczących się w polityce parlamentarnej. Nie oznacza to jednak, że wszyscy badani skupieni są wokół projektów niszowych i peryferyjnych. O ile w odniesieniu do radykałów lewicowych można mówić o działalności w ramach niewielkich organizacji 
i grup, liczących kilku lub kilkunastu członków, o tyle sytuacja ma się wręcz odwrotnie w przypadku prawicowej ekstremy, skupiającej w demonstracjach, protestach i manifestacjach czasem kilkadziesiąt tysięcy osób. Wszyscy oni prowadzą zarówno działania konwencjonalne, jak i niekonwencjonalne, często też nielegalne.

\begin{tabular}{|l|l|}
\hline badany & autoidentyfikacja \\
\hline Michał & komunista \\
\hline Bartek & komunista \\
\hline Olek & anarchista \\
\hline Kamil & skrajna prawica \\
\hline Mariusz & skrajna prawica \\
\hline Roman & skrajna prawica \\
\hline
\end{tabular}

Nie ma wątpliwości, że lewicowi ekstremiści walczą nie tylko o zmianę rządzących, ale również i obalenie systemu. Podstawą ich zaangażowania nie jest bowiem niezadowolenie czy niechęć do obecnie sprawujących władzę, ale brak akceptacji ustroju liberalno-demokratycznego. Podważają system polityczny; nie uczestniczą w wyborach. Uważają, że obecny system nagradza bierność i obojętność. Poprzez swoje działanie, sprowadzające się najczęściej do zbierania podpisów pod petycjami, organizacji debat, protestów czy demonstracji, chcą przyczynić się do realizacji wielkiego projektu zmiany świata na lepszy. Nastawieni idealistycznie i radykalnie głęboko wierzą że można pokonać kapitalizm, wyzysk i niesprawiedliwość. Peryferyjne położenie względem dominujących narracji nie zniechęca ich do systematycznego, pełnego pasji i nadziei działania.

Prawica wyznaje i dąży do różnych celów. Jedni żądają aby znienawidzona władza, utożsamiana z komunistami, postkomunistami i liberałami wywodzącymi się z partii obecnie rządzącej, została zastąpiona przez władzę prawdziwych Polaków, katolików i patriotów. Inni chcą wręcz obalenia „republiki okragłostołowej”. Krytyka kierowana jest najczęściej pod adresem wrogich mediów, wszechobecnej tolerancji i poprawności politycznej. Prawicowi radykałowie walczą z systemem, który, w ich przekonaniu, odrzuca patriotyzm, kreuje pseudoautorytety czy jest wręcz antypolski. Atakują postawy i zachowania sprzeczne z ich moralnością i poczuciem estetyki. Uczestniczą w ruchach narodowych, gdyż wierzą, że jeszcze Polska będzie Polska, czyli miejscem przyjaznym „prawdziwym” Polakom. Elementem 
łączącym oba skrajne środowiska jest kontestacja obecnego systemu. Urzeczywistnienie celów politycznych uświęca stosowanie metod niekonwencjonalnych i nielegalnych, na które nie ma przyzwolenia w demokratycznym państwie.

Środowiska (skrajnie) lewicowe, mimo zaangażowania intelektualnego, naukowego i wielu starań, nie potrafią zaistnieć w świadomości szerszej rzeszy młodych Polaków. Nie wydają się równie atrakcyjne jak ugrupowania prawicowe, które potrafią zmobilizować znacznie większe masy młodych ludzi. Niezadowolonych z dzisiejszej polityki demokratycznej - co widzimy co roku między innymi 11 listopada - przejmują organizacje o charakterze radykalnie prawicowym, do których należą moi młodzi badani. Wielokrotnie w czasie naszych rozmów chwalą się oni swoją siłą, liczebnością oraz jednością.

Mimo iż obecnie obie grupy radykałów odrzucają możliwość wejścia do polityki partyjnej, ekstremiści prawicowi mają znacznie większe szanse na zaistnienie $\mathrm{w}$ zinstytucjonalizowanej polityce $\mathrm{w}$ przyszłości niż ekstremiści lewicowi. Popularność oraz rosnące poparcie dla skrajnie prawicowych organizacji, szczególnie wśród młodych ludzi, daje nadzieję na karierę polityczną. Poza tym na scenie politycznej działają dziś partie, które są oni gotowi poprzeć lub też już popierają. Najlepszym przykładem jest Kamil. Należał niegdyś do młodzieżówki PiS, jednak widząc i obserwując codzienną praktykę funkcjonowania tej partii, opuścił ją bez żalu: Ja bytem też, ale odszedtem, bo mnie karierowiczostwo nie interesuje. W każdej młodzieżówce sq ludzie różni. Często w pisowskiej nie mieli nawet pogladów prawicowych. Sa, żeby zrobić karierę. No to sq frajerzy totalni. Ja nie potrafię z takimi ludźmi. [...] Tylko kombinuja, żeby pójść pokazać się przed kamerami. Tutaj coś, tam zrobić jakaśs akcję, żeby przypodobać się szefom. Nienawidze karierowiczostwa.

Zupełnie inaczej sprawa wygląda w przypadku komunistów, którzy nie widzą najmniejszej możliwości poparcia jakiejkolwiek mainstreamowej partii. Anarchista z kolei, z racji wyznawanej ideologii, jest przeciwnikiem wszelkiego życia partyjnego oraz instytucjonalnej polityki w ogóle, z której w pełni świadomie sam siebie wykluczył. Można przypuszczać, że jeśli nie zajdą w Polsce znaczne zmiany systemowe, to żaden z lewicowych bohaterów badania nie będzie odgrywał większej politycznej roli. Ich organizacje działają nielegalne lub poza główną debatą medialną. Szanse zaistnienia na politycznym rynku są zatem mocno ograniczone.

Elementem wspólnym, bardziej odnoszącym się do osobowości ekstremistów niż ich działań, celów, metod czy dróg edukacyjnych, jest również 
ideowość wśród bezideowych rówieśników. Młodzi ludzie pozostają dziś w większości obojętni. Nie angażują się w politykę. Świat obok wcale nie spotyka się z ich zainteresowaniem. Liczy się tu i teraz. Niezgoda, frustracja czy krytycyzm zamieniły się $\mathrm{w}$ apatię lub alienację, zapewne również i w bezradność. Większość młodych Polaków nie identyfikuje się z żadną $\mathrm{z}$ grup politycznych. Ich udział w wyborach, demonstracjach czy zwykłe zainteresowanie sprawami publicznymi są znikome. Również deklaratywne określenie ideologicznych preferencji młodzieży jasno świadczy o ich braku. Na przeciwległym biegunie znajdują się ekstremiści polityczni, których o brak idealizmu posądzić nie można. Kontestująi nie zgadzają się na niesprawiedliwość, deformację czy wyzysk. Mają wyobrażenie o idealnym świecie; na co dzień jednak stykają się z przejawami chorej rzeczywistości, jakże odbiegającej od tej oczekiwanej. Szukają zatem środowisk, które pomogłyby im zrozumieć przyczyny takiego stanu rzeczy i stworzyć receptę na wyjście $\mathrm{z}$ kryzysu. Badani doskonale wpisują się w ten teoretyczny portret młodego pokolenia. Sami głęboko wierzą, że staną się aktywnymi aktorami oczekiwanej zmiany społecznej. Oba środowiska, co jest zrozumiałe ze względów ideologicznych, oczekują jednak zmiany w zupełnie innym kierunku.

Przechodząc do głównego wątku rozważań na temat edukacyjnych biografii politycznych ekstremistów, przyjrzę się roli poszczególnych instytucji życia społecznego, a także sensom i znaczeniom nadawanym im przez badanych radykałów, w szczególności rodzinie, szkole, subkulturom oraz mediom. Wszyscy moi respondenci na różny sposób odeszli od drogi aprobowanej, wyznaczonej i przewidzianej. Skręcili mocno na prawo lub lewo, idąc $\mathrm{w}$ przeciwnym kierunku niż ten, który zakładają i projektują instytucje publiczne. Podążają drogą zupełnie nieaprobowaną przez istniejący system i jego organizacje.

Najbardziej widoczna jest całkowicie różna rola rodzin. Prawicowi badani swoje poglądy i przekonania w największym stopniu zawdzięczają właśnie środowiskom rodzinnym. Zdecydowanie wskazują na rodzinę, w tym szczególnie na ojca, jako głównego twórcę ich poglądów politycznych. W środowisku rodzinnym młodzi prawicowcy znajdowali się pod bezpośrednim i jawnym wpływem dominującej ideologii, ograniczanej do popierania konkretnej partii politycznej, ideologii uznawanej, wspieranej i otwarcie szerzonej lub nawet drastycznie narzucanej przez środowisko rodzinne. Silny i bezpośredni wpływ ojca widoczny jest na całej dotychczasowej drodze politycznej badanych prawicowych radykałów. Poglądy i postawy ojców zaważyły na dalszych wyborach i zdeterminowały ich działania oraz podejście do świata oraz polityki. Badani wskazują na ojców, którzy stanowili 
drogowskazy moralne i polityczne, byli przewodnikami światopoglądowymi i ideologicznymi w świecie postpolitycznej obojętności.

Roman nie ukrywa: tutaj wszystko z ojca na syna przechodzilo. Te wszystkie rzeczy, te wszystkie poglady. Podobnie jest w domu Kamila: U mnie zawsze w rodzinie byty poglady prawicowe. Już od dziadka, potem przez ojca to przeszło na mnie [...]. Cala rodzina jest prawicowa. Poglądy i orientacje polityczne $\mathrm{w}$ obu domach przekazywane są z pokolenia na pokolenie. $\mathrm{W}$ rodzinach nie występują inne polityczne alternatywy. Wszyscy poruszają się jasno wyznaczonym szlakiem i nie zbaczają z niego. Środowisko rodzinne, w którym polityka jest wszechobecną dziedziną życia, może oddziaływać na badanych silniej niż szkoła czy rówieśnicy. Rodzina proponuje jasną ideologicznie wizję świata, która często jest sprzeczna z tą głoszoną w szkole i mediach. Mimo to młodzi konsekwentnie opowiadają się za wartościami przekazanymi im w domu. Niezłomnie i stanowczo stoją po stronie poglądów zakorzenionych w tradycjach rodzinnych. Nie wyobrażają sobie innych wyborów. Myślą i postępują zgodnie z tradycją rodzinną. Poglądy zaszczepione przez rodzinę trwale definiują ich polityczny krajobraz. Transmitowany z pokolenia na pokolenie patriotyzm przechodzi w zaangażowanie polityczne po stronie współczesnej prawicy.

Zupełnie odmiennie przedstawia się sytuacja komunistów i anarchisty. Oni nie znajdują w rodzinie najmniejszego poparcia dla głoszonych przez siebie poglądów. Co więcej, ich idee i postawy spotykają się z wyraźną dezaprobata, brakiem uznania czy szacunku. Rodzice zdziwieni, zaskoczeni, a nawet oburzeni są poglądami młodych, gdyż sami nigdy nie głosili podobnych. W żaden sposób nie potrafią wytłumaczyć i zrozumieć ideologii popieranych przez synów. Michał opowiada o ojcu: Kiedyś po któtni na temat moich pogladów stwierdzil, że jestem idiota. Także drugi z komunistów, Bartek, spotyka się z pewnym ostracyzmem w domu: Matka uważa, że jestem wariatem. Moja matka uważa, że jestem wariatem. Mój ojciec też. Badani, którzy wyznają inne poglądy niż ich rodzice, konfrontowani są z próbami ośmieszania i nakłaniania ich do zredefiniowania i zmodyfikowania własnych stanowisk. Dziś, kiedy ich światopoglądy są już znacznie bardziej ugruntowane, a oni zdecydowanie silniej politycznie „uświadomieni”, rodzina zaniechała przekonywania ich do podążania inną ścieżką polityczną.

Wyraźnie widać, że w przypadku skrajnej lewicy rodzina nie odegrała jakiejkolwiek roli. Rodzina posiada natomiast niezwykłą wręcz moc wychowania do skrajnie prawicowych poglądów. Zapewne bierze się to ze specyfiki polskiej historii i kultury, w której poglądy konserwatywne i prawicowe, o czym świadczą przypadki badanych, przekazywane są z pokolenia na po- 
kolenie. Niebywała rola kościoła wzmacniała i ciągle wzmacnia poglądy zachowawcze, a często wręcz skrajnie prawicowe. $Z$ drugiej strony, po okresie dyktatury komunistycznej, ideologie lewicowe zostały, w oczach większości, skompromitowane i ośmieszone. Przyznawanie się do bycia anarchistą czy komunistą, szczególnie wśród pokoleń starszych, a więc rodziców badanych, jest rzadkością. Poglądy skrajnie prawicowe znajdują akceptację i uprawomocnienie. Jeśli nie w mediach głównego nurtu i publicznych dyskursach polityków, to na pewno są głoszone i przekazywane na stopie prywatnej i rodzinnej, mniej lub bardziej jawnie i intencjonalnie. Dziedzictwo rodziny jest w niektórych przypadkach aż nadto widoczne i może być kłopotliwe z demokratyczno-liberalnego punktu widzenia. Poglądy, często skrajne i nie do zaakceptowania w państwie prawa, są bowiem stale odtwarzane i reprodukowane. Przechodzą z pokolenia na pokolenie. Siła i skuteczność rodzinnej socjalizacji nie znajduje przeciwwagi w działaniach innych instytucji. W przypadku skrajnie prawicowych rozmówców rodzinę należy uznać bez wątpienia za najważniejszy czynnik bezpośredniej socjalizacji politycznej.

Szkoła w przypadku całej skrajnej szóstki odegrała raczej znikoma, jeśli w ogóle jakąkolwiek, rolę w radykalizacji nastrojów. Komunista Michał wspomina: w liceum miatem historyczkę bardzo histerycznq. Nie dało się $z$ niq $w$ ogóle porozmawiać. Wielu nauczycieli nie aprobowało dyskusji, a tym bardziej poglądów niemieszczących się w dopuszczalnych granicach. Moi badani nie mieli zatem okazji do rozmowy na temat swoich poglądów, znacznie różniących się od tych uznawanych przez ogół środowiska szkolnego. Michał przyjął chyba najpowszechniejszą postawę wśród ekstremistów politycznych: unikał rozmów, konfliktów czy w ogóle wchodzenia w jakiekolwiek spory. $W$ szkole starałem się nie wchodzić w konflikty z nauczycielami, bo uważatem, że nie ma najmniejszego sensu kłócić się z nimi o sprawy polityczne. Prawicowiec Kamil zauważał, że na studiach: Szczególnie przy tematach politycznych byli po jednej stronie i wyraźnie za obecna partia rzqdzqca, drugq atakujac, ośmieszajac. Ekstremiści z reguły nie znajdywali poparcia nauczycieli, gdyż ich poglądy nie mieściły się w ramach demokratycznego konsensusu. Wyjątek stanowił nauczyciel historii w szkole Romana, który zarażał pasja. Starał się przekazywać uczniom wartości patriotyczne, zachęcał do pielęgnowania kultury i polskiej tradycji. Wzmacniał i utrwalał poglądy prawicowe, wcześniej już przekazywane synowi przez ojca. Mimo tych kilku przypadków, doświadczenia szkolne i „uczniowska” codzienność pozostają bez większego wpływu na proces konstruowania poglądów młodych politycznych ekstremistów. Szkoła ani nie nakłaniała, ani nie budowała ich zainteresowania i zaangażowania politycznego. Nie prze- 
ciwdziałała i nie zapobiegała także stawaniu się przez nich coraz aktywnymi radykałami. Przyjmowała postawę bierną i wycofaną.

Znaczenie szkolnej edukacji formalnej w zakresie polityki mogłoby zostać właściwie w przypadku ekstremistów pominięte, gdyby nie fakt, że to właśnie instytucja szkoły miałaby/ma budować barierę dla poglądów nieakceptowanych w demokratycznej polityce, do których system prawny i instytucje publiczne zaliczają zarówno stanowiska skrajnie lewicowe, jak i prawicowe, stosując pomiędzy obiema skrajnościami znak równości.

„Tabu zostało złamane, wiemy już, że nie żyjemy na najlepszym z możliwych światów. Wolno nam, a nawet jesteśmy zobowiązani myśleć o alternatywach dla niego"s. Współczesna epoka zamrożenia politycznego charakteryzuje się tym, że znaczna część społeczeństwa, w tym także młodego, jest zdemobilizowana i zniechęcona do wszystkiego, co może mieć znamiona działalności wspólnotowej. Mamy do czynienia z odpolitycznieniem publicznej edukacji i separacją młodych od polityki. Narzucenie im modelu życia, w którym mają skupić się na sobie, zająć prywatnymi sprawami, dążyć do osobistego sukcesu, zostawia miejsce nieformalnym organizacjom, które w państwie i polityce bez alternatyw stają się jedyną ofertą dla tych, którzy chcą wyrazić swoje niezadowolenie i bunt, dla tych nielicznych młodych, którzy myślą w kategoriach wspólnotowości, społeczeństwa czy narodu. Szkoła wycofuje się z walki o „upolitycznionego” obywatela, licząc, iż całą energię włoży on w pracę zawodową lub życie rodzinne, ewentualnie opowie się po stronie wspieranych przez system, media czy prywatny kapitał ideologii czy też sformalizowanych i hierarchicznych grup. Moi badani poszli jednak zupełnie inną drogą. Słuchając i obserwując badanych ekstremistów, przyznać należy, iż instytucja szkolna nie przeciwdziała w wystarczającym stopniu negatywnym stereotypom, dyskryminacji i homofobii. Wielu młodych zaangażowanych przesiąkniętych jest ideologią wrogości, nienawiści i niechęci do obcych, innych czy inaczej myślących. Szkoła nie próbowała lub nie potrafiła zapobiec takim postawom ani ich wykorzenić. Jej słabość i brak skuteczności w budowaniu poparcia dla systemów demokratyczno-liberalnych musi niepokoić. Slavoj Žižek pisał: „Dziś prawdziwa wolność myślenia oznacza wolność kwestionowania panującego liberalnodemokratycznego postideologicznego konsensusu - albo nie znaczy nic" Idąc tropem słoweńskiego filozofa, badani wpisują się w obraz ,prawdziwej wolności myślenia”, gdyż otwarcie i stanowczo kwestionują ów konsensus.

\footnotetext{
${ }^{5}$ S. Žižek, Rok niebezpiecznych marzeń, Warszawa 2014, s. 145.

6 Tenże, Rewolucja u bram, Kraków 2007, s. 306.
} 
Szkoła nie nauczyła ich konformizmu, posłuszeństwa i akceptacji obecnego systemu. Badani występują przeciwko instytucjom demokracji liberalnej.

Słusznie zauważył Florian Znaniecki, że:

Znaczenie grup rówieśników jako czynnika wychowawczego zależy od tego, w jakiej mierze przyczyniają się one do urobienia jednostki pod względem społecznym i przygotowania jej do udziału w grupach dojrzałych [...]. Wszędzie indziej młodociany osobnik zajmuje stanowisko podporządkowane i wyrabia w sobie tylko te strony swej osobowości społecznej, które na tym stanowisku mogą się czynnie objawiać. $\mathrm{W}$ grupie rówieśników natomiast występuje w roli równouprawnionego członka, z którym inni liczą się nie tylko jako z przedmiotem swojego działania, ale również jako podmiotem społecznym ${ }^{7}$.

Jednostka wśród rówieśników nie jest poddawana presji ze strony posiadających władzę i z góry zakładany monopol na prawdę. W środowisku rówieśniczym ludzie zmuszeni są ustalać i przestrzegać reguł wzajemnie wypracowywanych i aprobowanych, często różniących się od norm obecnych w rodzinie czy szkole.

Zdecydowanie widoczna i kluczowa jest rola subkultur i środowisk młodzieżowych w socjalizacji radykałów politycznych. Zarówno lewicowi, jak i prawicowi ekstremiści podkreślają znaczenie ruchów młodzieżowych w procesie stawania się aktywistą politycznym. Olek: Należatem do subkulturowej alternatywy. W Bielsku-Białej nie było jakiegoś podziału na Punki, rastamanów, itd. Była jedna grupa, no i barwna zreszta. Trzy osoby stamtad zorganizowaly demonstracje antyfaszystowska, w której wziq̨em udzial. Demonstracja zrzeszyla jakieś 200 osób i to byla pierwsza demonstracja, $\boldsymbol{w}$ której wziq̨em udziat [...]. Olek zwraca uwagę na zjawisko solidarności wewnątrzgrupowej. Identyfikował się ze środowiskiem atakowanym przez narodowców i skrajnych prawicowców, dlatego zainteresował się istotą konfliktu między konkretnymi światopoglądami oraz grupami, co w dłuższej perspektywie zaprowadziło go w kierunku anarchizmu. Przedstawiciele „subkulturowej alternatywy” mogli liczyć na wzajemne wsparcie i solidarność. Badany zwraca również uwagę na uprzedzenia i wzajemną niechęć poszczególnych subkultur, które, wyznając sprzeczne ideały i opowiadając się za zgoła odmiennymi światami, rywalizują ze sobą nie tylko na hasła i argumenty. Nastawione do siebie wrogo i agresywnie posługują się przemocą. To jeden z głównych wyróżników ekstremistów politycznych, któ-

\footnotetext{
${ }^{7}$ F. Znaniecki, Socjologia wychowania, Warszawa 2001, s. 85.
} 
rzy znajdują usprawiedliwienie i wytłumaczenie dla stosowania instrumentów polityki nielegalnej. Również komunista Bartek zwraca uwagę na rolę subkultur w dochodzeniu do konkretnego światopoglądu: Nie wiem, chyba może z tego, że jakiejś tam muzyki punkowej stuchatem. Takie rzeczy maja wpływ na młodego człowieka. To jakoś przez znajomych zacząlem stuchać, tam masz takie teksty, że wojna jest niedobra, że bieda jest smutna. Bartek, podobnie jak Olek, należał do subkultury jednoznacznie kojarzonej z lewica. Badany przypuszcza, że grupa kolegów odegrała istotną rolę w kształtowaniu jego poglądów. Zauroczony punkiem, z którego płynie wolnościowe i równościowe przesłanie, umacniał się w swoich przekonaniach.

Z kolei w przypadku trójki prawicowych badanych widoczny jest silny związek z subkulturą kibicowską. Wszyscy oni budują triadę prawica - patriotyzm - kibicowanie. Swoje prawicowe przekonania i zaangażowania wiążą ze środowiskiem, w którym dorastali, jednoznacznie utożsamiając kibicowanie z postawą prawicową. Wskazują na silnie zideologizowaną subkulturę kibicowską, w której prawicowość stanowi jedyną słuszną ideę. W przypadku badanych „kibicowanie” zarezerwowane i ograniczone jest do konkretnej ideologii politycznej, utożsamianej z odwagą, bohaterstwem i walecznością. Roman przyznaje otwarcie: Kibicowanie pokrywa się z patriotyzmem, z prawa strona [...]. Badany łączy sympatie kibicowskie z preferencjami politycznymi. Jedni kibice mają być prawicowi, a inni bardziej lewicowi. Sport postrzega jako dziedzinę nierozerwalnie splecioną z polityką. Mariusz wiele „zawdzięcza” subkulturze kibicowskiej: Wiesz, może też była taka sytuacja, że ja kiedyś jeździłem na mecze Legii. No i tam na tej Legii też byly takie prawicowe poglady. I może to się stad też wzięto. Tak zaczęło to się wszystko kleić. W przypadku Mariusza początki politycznego zaangażowania łączą się bezpośrednio z kibicowaniem. Wyjazdy na Legię i obcowanie z młodzieżą prawicową stanowiły niejako ,polityczną inicjację" badanego. O silnym wpływie grupy rówieśniczej nie tylko na orientację ideologiczną, ale także na postrzeganie innych ludzi, wyznawane wartości i aprobowane normy zachowania świadczą ponadto słowa Kamila, który odszedł z młodzieżówki PiS-u, ponieważ nie chciał zaakceptować bezideowości jej licznych członków: Ja nie potrafię z takimi ludźmi. Jestem wychowany na Legii. Środowisko zaangażowanych kibiców jest dla badanego synonimem uczciwości, poświęcenia i ideowości. Gardzi karierowiczostwem, interesownością, obłudą. Wychowanie na stadionie utożsamia z odwaga, honorem i ideowością.

Ludzie, popijając $\mathrm{w}$ pubach piwo, idąc do restauracji, kina lub na koncert muzyki alternatywnej, często spontanicznie poruszają tematy związane z polityką, wpływając nawzajem na swoje poglądy, postawy i wartości. Mimo 
braku intencjonalności, przebywanie wśród rówieśników determinuje polityczne orientacje. Podobnie jak w rodzinie, reprezentowanie odmiennych, sprzecznych postaw wobec polityki jest zachowaniem nieakceptowanym i stanowiącym zagrożenie dla jedności grupy, co znajduje odbicie chociażby w grupach kibicowskich, gdzie kibicowanie jednemu klubowi oznacza popieranie konkretnych ideologii. Sprzeniewierzenie się politycznym wzorcom grozi wykluczeniem. Subkultury pokazują, w przeciwieństwie do dosyć konserwatywnych modeli rodzinnych i szkolnych, że mogą stanowić motor napędowy zmian. Najlepszym przykładem są młodzieżowe grupy protestu i buntu, do których właśnie należą moi badani. One w sposób najsilniejszy wymykają się spod kontroli państwa i jego instytucji, często pozostając poza jakąkolwiek kontrolą. Przypadki ekstremistów tylko potwierdzają tezę o nieprzewidywalności socjalizacji politycznej przez grupy młodzieżowe. Proces socjalizacji politycznej wśród grup rówieśników przebiega niesystematycznie, spontanicznie i bezplanowo. Nie jest działaniem celowym, regularnym i przewidywalnym, często natomiast skutkiem pobocznym głównego nurtu zainteresowania. W społeczeństwach nowoczesnych, odchodzących i zrywających z tradycyjnymi instytucjami życia społecznego, grupy rówieśnicze posiadają jak pokazują przypadki ekstremistów politycznych, silny potencjał socjalizacyjny.

Chyba najmniejsze wątpliwości budzi rola mediów, które w bardzo podobny sposób traktowane są przez obie grupy ekstremistów politycznych. Należy podkreślić ich wielopłaszczyznowy i wielokierunkowy wpływ na poglądy, postawy i opinie dotyczące całej sfery polityki. Media umożliwiają przede wszystkim zdobycie niezbędnej informacji o wydarzeniach, programach politycznych, politykach, opiniach, itp. Wszyscy badani niezwykle krytycznie odnoszą się do mediów głównego nurtu, podważając zawarte w nich treści, autorytet dziennikarzy, a przede wszystkim jakość przekazu docierającego do odbiorców. Michał, określający się mianem komunisty, przyznaje otwarcie: $w$ tym potoku beznadziejnych newsów musiatbym się odnajdywać z informacjami, które sq dla mnie ważne [...]. Co mnie obchodzi, że Palikot z Tuskiem się kłóci?

W opinii ekstremistów media głównego nurtu proponują banalne teksty i rozmowy. Otumaniają odbiorców kolejnymi jałowymi, na wskroś sztucznymi sporami. Stąd też osoby o poglądach bardziej radykalnych i niekonwencjonalnych kierują poszukiwania w stronę mediów niszowych, zajmujących się inną tematyką i propagujących inne obrazy świata. W opinii respondentów nastawionych antysystemowo, radykalnie atakujących scenę polityczną, zapoznawanie się z ofertą mediów głównego nurtu pozbawione 
jest głębszego sensu. Są zbyt przewidywalne i jednokierunkowe. Zajmują się sprawami małej wagi, pomijając kwestie prawdziwie istotne. Roman, skrajny prawicowiec, każe mi wyobrazić sobie jakaśs partię, która mówi: tak zamieszki wywołali ludzie, którzy sq wkurzeni na system, którzy nie akceptuja tego, co się dzieje i dlatego rzucali kamieniami [...]. Wiesz jak to by się $w$ mass mediach sprzedało? Roman woli koncentrować się na mediach niezależnych, bowiem te największe i najpotężniejsze nie próbują znaleźć i obiektywnie przedstawić przyczyn niezadowolenia. Ograniczają się do przekazu migawek z demonstracji; kamerę zatrzymują na momentach, kiedy padają kamienie, całkowicie upraszczając i ośmieszając istotę sprawy.

Badani narzekają na brak pluralizmu w mediach, na jednowymiarowość przekazywanego obrazu. Romana denerwuje, że na trzech stacjach leci to samo. Kamil, prawicowiec, zauważa: W tej chwili nie ma dziennikarzy o nieshusznej linii. Nie ma dziennikarzy niepoprawnych politycznie. Nie ma czegoś takiego. Sprzeczaja się tylko ludzie z Newsweeka z Przegladem czy Polityki z Wprost. To sq ci sami ludzie, z tego samego systemu. Granice pluralizmu mediów głównego nurtu przebiegają w sposób dla wielu nie do zaakceptowania. Liczni badani nie znajdują w nich przestrzeni dla siebie. Lokują się na zewnątrz, zostają zmuszeni do kontestacji i szukania swojego miejsca gdzie indziej. Dominujące dyskursy, obecne w telewizji i publicystyce, tylko pozornie stwarzają wrażenie konkurencyjnych. W rzeczywistości różnice między nimi są niewielkie lub czasem tylko symboliczne. Konsekwentnie umacniane jest natomiast wyobrażenie jakoby pewne idee w Polsce w ogóle nie istniały. One są jednak obecne, o czym świadczą poglądy moich rozmówców, którzy wespół ze swoimi organizacjami nie mają na ogół szans zagościć w mediach tradycyjnych. Jedynie przy okazji większych zamieszek lub awantur mogą liczyć na zainteresowanie mediów. Inaczej ich reprezentanci nie są zapraszani do studiów telewizyjnych czy nawet do udziału w młodzieżowych debatach.

Kamil poświęca w swojej narracji wiele miejsca opisowi mediów, które ocenia bardzo negatywnie. Manipulacje, ujednolicony przekaz, brak różnorodności poglądów tłumaczy koncentracją głównych mediów w rękach jednej spółki: Bo jest totalna propaganda medialna. Wtedy jeszcze nie byto takiej jak teraz. Bo teraz masz wszędzie. Wśród młodzieży o poglądach zarówno z lewej, jak i prawej strony, lokujących swoje orientacje polityczne na zewnątrz parlamentarnych podziałów, pada wiele zarzutów pod adresem Gazety Wyborczej i TVN-u, mediów, które jawią się jako główni manipulatorzy i demagodzy. Są one utożsamiane z obrońcami postideologicznego układu, który skutecznie oszukuje społeczeństwo. 
Mimo zasadniczych różnic w poglądach, wartościach czy drogach politycznych moich respondentów, ocena mediów pozostaje niemalże identyczna. Ekstremiści upatrują w nich zarówno przyczynę braku zainteresowania ogółu społeczeństwa sprawami publicznymi, jak i poparcia dla głoszonych przez ich środowiska ideałów. Zmuszeni są do prezentowania swoich poglądów w mediach niezależnych lub samodzielnego kreowania przekazów medialnych. Zwłaszcza te najnowsze media tworzą dogodną przestrzeń do artykulacji i rozpowszechniania poglądów. Grupy, organizacje czy jednostki „upośledzone” mogą wyrażać własne zdanie, nakłaniać i przekonywać innych do słuszności swoich idei. Internet daje możliwość prezentowania głosów wykluczanych i nieakceptowanych w mediach mainstreamowych. Niezależność licznych portali internetowych, stanowiących alternatywne źródła informacji, jest zarówno podkreślana przez ich twórców, jak i odbiorców. Nowe niszowe media stanowią wyraźną alternatywę wobec dominujących prądów. Radykalnie nastawieni do rzeczywistości młodzi ludzie szukają i znajdują $\mathrm{w}$ mediach alternatywnych czy niezależnych komentarze i opisy wydarzeń ignorowanych przez media głównego nurtu. Poszerzają one zakres debaty publicznej, dopuszczając do głosu poglądy pomijane i defaworyzowane. Internet pozwala unikać mechanizmów kontrolnych stosowanych przez władzę i dominujące media. Współcześnie władza jest determinowana dostępem do komunikacji i sieci. Ani państwo, ani prywatny kapitał nie posiadają całkowitej władzy nad Internetem, który wymyka się spod kontroli w sytuacji, gdy większość obywateli posiada nieograniczony dostęp do sieci i możliwość wejścia na niszowe czy radykalne strony. Media alternatywne, w dużej mierze funkcjonujące w cyberprzestrzeni, podważają hegemoniczne wizje świata, upowszechniając alternatywne narracje. Zaangażowane w kształtowanie innej przyszłości funkcjonują w opozycji do głównego nurtu. Znajdują szczególnie silne i liczne zaplecze wśród młodych ludzi. Internet jest szansą i platformą prezentowania (jeszcze) alternatywnych opinii i (jeszcze) niepopularnych osób, niemogących przebić się w mediach głównego nurtu. Na znaczenie nowych mediów w rozwoju ruchów społecznych i aktywizacji młodych ludzi wskazuje chociażby Manuel Castells pisząc „Internet i komunikacja bezprzewodowa miały kluczowe znaczenie dla współczesnych usieciowionych ruchów społecznych"».

Przedstawione biograficzne trajektorie młodych ekstremistów politycznych wskazują na dosyć przejrzyste role i znaczenia, które przypadają w udziale konkretnym instytucjom socjalizacyjnym, co w kontekście dzi-

${ }^{8}$ M. Castells, Sieci oburzenia i nadziei. Ruchy społeczne w erze Internetu, Warszawa 2013. 
siejszego zamętu znaczeniowo-pojęciowego może zaskakiwać. Narracje badanych ekstremistów przybliżają podobieństwa doświadczeń wynikających chociażby z miejsca zajmowanego w publicznej przestrzeni i sensów działania. Mimo wspólnoty wynikającej z przynależności do rodziny „ekstremizmów”, oba „izmy” znacznie różnią się od siebie, zarówno wartościami, ideałami, kierunkami działania, jak i popularnością czy znaczeniem. Analiza edukacyjnych kontekstów pozwala określić „miejsca”, „momenty” i „okoliczności”, w których młodzi mają szansę stawać się bardziej niepokornymi, autonomicznymi, krytycznymi i niekonwencjonalnymi działaczami politycznymi. Jednak czy taka „niezależność” może nieść i niesie za sobą pozytywne skutki i konsekwencje?

\section{Educational Biographies of Political Extremists: Similarities and Differences (Summary)}

The article concerns attitudes, aims and experiences of the left-wing and rightwing, young political radicals, during their journey of becoming politically engaged. The analyses and interpretations of narrative interviews with political radical activists allow to present similarities and differences in their life and educational trajectories. The main goal of this article is to reconstruct the role of the political socialization agendas and their meaning in the process of becoming politically engaged in a community known as politically radical.

Keywords: politics, democracy, extremism, youth, socialization

\section{Biografie edukacyjne ekstremistów politycznych. Podobieństwa i różnice (Streszczenie)}

Artykuł traktuje o postawach, celach oraz doświadczeniach lewicowych i prawicowych „ekstremistów” politycznych, zdobytych podczas ich drogi stawania się osobami politycznie zaangażowanymi. Interpretacja wywiadów narracyjnych przeprowadzonych z politycznymi radykałami pozwala na identyfikację różnic i podobieństw w ich trajektoriach życiowych i edukacyjnych. Kluczowym celem artykułu jest rekonstrukcja ról głównych agend socjalizacyjnych i ich znaczenia w procesie stawania się zaangażowanym politycznie $\mathrm{w}$ środowiskach powszechnie uznawanych za radykalne.

Słowa kluczowe: polityka, demokracja, radykalizm, młodzież, socjalizacja 